\title{
Directional changes in plant assemblages along an altitudinal gradient in northeast Brazil
}

\author{
Santos, BA. ${ }^{\mathrm{a}, \text { Barbosa, }}$ DCA. ${ }^{\mathrm{b}}$ and Tabarelli, M. ${ }^{\mathrm{b} *}$ \\ ${ }^{a}$ Coordenação de Pesquisas em Silvicultura Tropical, Instituto Nacional de Pesquisas da Amazônia, \\ Av. André Araújo 2936, CEP 69060-001, Manaus, AM, Brazil \\ bDepartamento de Botânica, Universidade Federal de Pernambuco, \\ Av. Prof Moraes Rego s/n, CEP 50670-901, Recife, PE, Brazil \\ *e-mail: mtrelli@ufpe.br
}

Received November 17, 2005 - Accepted December 20, 2005 - Distributed November 30, 2007

(With 1 figure)

Plant assemblage organization along physical environmental gradients remains a central issue of community ecology whether it is analyzed on local, regional or continental scales. In the case of neotropical forests, several studies have identified remarkable differences between dry and moist forests in terms of vegetation structure, woody plant species composition, plant species richness and the relative contribution of life-history strategies including life form, seed dispersal and pollination mode (see Gentry, 1983, 1988; Bullock, 1995; Medina, 1995; Murphy and Lugo, 1996). Similar patterns have been found in neotropical forests covering altitudinal gradients (Vázquez and Givnish, 1998). More than remarkable differences between patches of forests, the studies referred to earlier support the idea of gradual, directional and consequently predictable changes in the attributes of woody plant assemblages covering such gradients.

The caatinga vegetation is a kind of dry forest and scrub vegetation (sensu Pennington et al., 2000) which covers $730,000 \mathrm{~km}^{2}$ of northeastern Brazil. Throughout this region, caatinga vegetation covers flattened surfaces located preferentially between 300 and $500 \mathrm{~m}$ a.s.l. Vegetation types are constrained by $240-900 \mathrm{~mm}$ of annual rainfall (see a synthesis in Leal et al., 2003). Moreover, the caatinga surrounds dozens of high hills where the annual rainfall exceeds $1000 \mathrm{~mm}$. Tracts of the Brazilian Atlantic forest cover the top of these hills, and such enclaves of humid forests located in the caatinga semiarid region have been locally referred to as 'brejo forests' sensu Pôrto et al. (2004). Briefly, the caatinga and Atlantic forest border each other for hundreds of kilometres and form continuums of vegetation from dry seasonal forests or scrub vegetation in the inter planaltic depressions to semi-deciduous or even evergreen forests on the top of the hills - hereafter caatinga-brejo forest continuums. These continuous have already been completely cleared in most of the 47 brejos once recorded in the northeast of Brazil (see a synthesis in Pôrto et al. (2004).

Based on the ideas briefly discussed earlier, it is reasonable to expect both gradual and directional changes in the attributes of plant assemblages, which form the caatinga-brejo forest continuums. Precisely, we should expect a gradual increase in plant species richness and in the relative contribution of species within categories of life form, seed dispersal mode, fruit type and size as altitude/annual rainfall become higher (i.e., caatinga to Atlantic forest). In this paper, we test this prediction by analyzing species richness and the ecological composition of woody plant assemblages at four altitudinal levels along a caatinga-brejo forest continuum (500-1100 m a.s.1.), which is located between Triunfo and Serra Talhada municipalities (Pernambuco State). In this area, increasing levels of altitude are also correlated with (1) increasing levels of annual rainfall - nearly $600 \mathrm{~mm}$ at $500 \mathrm{~m}$ up to $1200 \mathrm{~mm}$ at $1100 \mathrm{~m}$; and (2) decreasing scores of average annual temperature $\left(26-18{ }^{\circ} \mathrm{C}\right.$ respectively; Ferraz et al., 1998).

Remaining patches of this vegetation continuum are currently distributed over $23 \mathrm{~km}$ of extension and they were assessed via plant surveys by Ferraz et al. (1998). These authors recorded liana, shrub and tree species at four altitudinal levels - 500, 700, 900, and $1100 \mathrm{~m}$ a.s.l. by a total sample of thirty $200-\mathrm{m}^{2}$ plots and random plant collections outside plots. We used the checklist provided by Ferraz et al. (1998), and classified its 149 woody plant species within categories of life form, seed dispersal, fruit type and fruit size according to criteria and procedures described by Tabarelli et al. (2003). By these procedures, we obtained the proportion of species within ecological categories in the four levels of altitude. Lack of information at two levels of altitude avoided comparisons based on rainfall.

In contrast to our expectations, plant species richness did not show a gradual increase along the gradient $\left(r_{\mathrm{s}}=0.5, \mathrm{P}>0.05\right)$ yet species richness in 900 and $1100 \mathrm{~m}$ of elevation was higher than in $500 \mathrm{~m}\left(\chi^{2}=17.1\right.$, $\mathrm{df}=1, \mathrm{P}<0.001 ; \chi^{2}=11.2$, $\mathrm{df}=1, \mathrm{P}<0.001$, respectively). This was also higher than in $700 \mathrm{~m}\left(\chi^{2}=27.8, \mathrm{df}=1\right.$, $\mathrm{P}<0.0001 ; \chi^{2}=9.5$, df $=1, \mathrm{P}<0.0001$, respectively). Precisely, species richness ranged from 42 to 70 species at $1100 \mathrm{~m}$ of altitude, which represented a significant increase of $71.4 \%$. The proportion of tree species also differed significantly within altitudinal categories $\left(\chi^{2}=9.5\right.$; $\mathrm{df}=3 ; \mathrm{P}=0.02)$. At $500 \mathrm{~m}$ of altitude, $52.4 \%$ of the species were trees, increasing gradually by $57.6 \%, 67.1 \%$ 
and $78.6 \%$ at $1100 \mathrm{~m}$, respectively (Figure 1a). Similarly, the percentage of vertebrate-dispersed species gradually increased from $35.7 \%(500 \mathrm{~m})$ to $65.7 \%(1100 \mathrm{~m}$; Figure $\left.1 \mathrm{~b} ; \chi^{2}=11.79 ; \mathrm{df}=3 ; \mathrm{P}=0.008\right)$. In contrast, we did not find any significant relationship between the altitude and both fruit type and size (Figures 1c,d).

Altitude is probably a spurious variable, which is in our site significantly correlated with those promoting more conspicuous biological effects such as average rainfall and temperature (see Lütge, 1997). To give one example, the relative contribution of shrubs decreases sharply while the contribution of trees increases within stands of caatinga vegetation covering gradients from very dry sites ( $<400 \mathrm{~mm}$ of average annual rainfall) to sites receiving $>800 \mathrm{~mm}$ (Andrade-Lima, 1981; Leal et al., 2003). The relative and absolute increase in trees, which usually replace part of the shrub species, also explain why moister patches of tropical forest and savannas are richer than drier sites (Andrade-Lima, 1981; Gentry, 1988) as observed in this study.

The underlying mechanisms driving these spatial variations of the attributes of plant assemblages certainly include differences in the water required by plant species showing different life-history traits, i.e. mechanisms based on plant-response to physical factors. Tabarelli et al. (2003), for example, argued that tree and shrub species that produce and have to maintain small or large fleshy fruits (i.e., moist-but-soft-skinned fruit) in lowrainfall areas within the caatinga or in those areas where rainfall is erratic would be negatively affected by long dry seasons and high evaporation/insolation during the moist season. On the other hand, several studies (e.g., Vázquez and Givnish, 1998; Brose and Tielbörger, 2005) have shown plant-plant and animal-plant interactions as biotic drivers of species distribution along physical gradients with remarkable impacts on the attributes of plant assemblages, particularly species richness, species composition and abundance of life-forms.

In the case of the caatinga-brejo forest continuums, further studies should investigate whether the patterns documented here result from the occurrence of narrowdistributed species (high habitat-specificity) and the consequent establishment of particular assemblages or alternatively if they result from the presence of large ecotonal

(a)
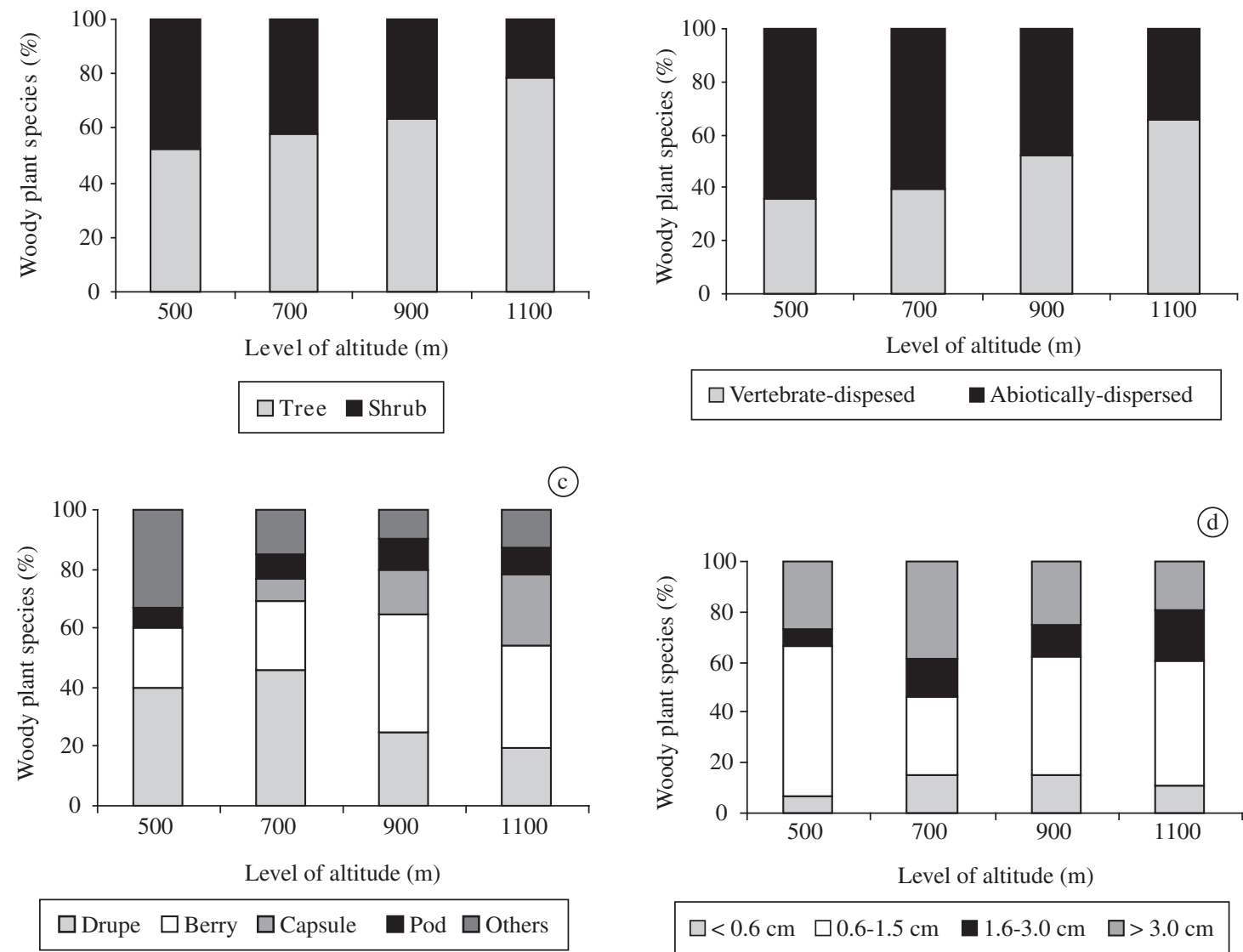

(c)

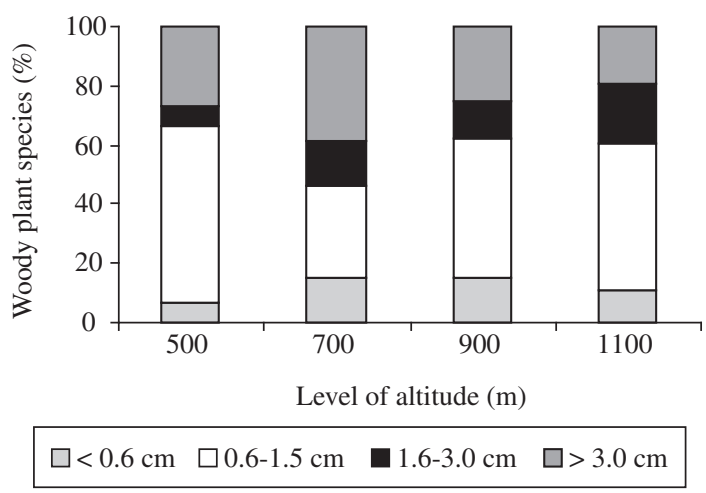

Figure 1. Percentage of woody plant species within categories of life form (a); seed dispersal mode (b); fruit type (c); and fruit size $(d)$ in four altitudinal levels in northeast Brazil $(n=149$ species). 
plant assemblages. Additionally, mechanisms driving plant species spatial distribution, which ultimately explain the attributes of plant assemblages, must be identified. Answers to these questions are essential to extend our knowledge concerning the evolutionary history of neotropical biotas, as well as the organization of plant assemblages along physical environmental gradients.

\section{References}

ANDRADE-LIMA, D., 1981. The caatinga dominium. Revista Brasileira de Botânica, vol. 4, no. 8, p. 149-163.

BROSE, U. and TIELBÖRGER, K., 2005. Subtle differences on environmental stress along a flood gradient affect the importance of inter-specific competition in an annual plant community. Plant Ecology, vol. 178, no. 1, p. 51-59.

BULLOCK, SH., 1995. Plant reproduction in neotropical dry forests. In BULLOCK, SH., MOONEY, HA. and MEDINA, E. (eds). Seasonally dry tropical forests. Cambridge: Cambridge University Press, p. 277-303.

FERRAZ, EMN., RODAL, MJN., SAMPAIO, EVSB. and PEREIRA, RCA., 1998. Composição florística em trechos de vegetação de caatinga e brejo de altitude na região do Vale do Pajeú, Pernambuco. Revista Brasileira de Botânica, vol. 21, no. 1, p. 7-15.

GENTRY, AH., 1983. Dispersal ecology and diversity in neotropical forest communities. Sonderband Naturwissenschaftlicher Verein Hamburg, vol. 7, p. 303-314.

-, 1988. Changes in plant community diversity and floristic composition on environmental and geographical gradients.
Annals of the Missouri Botanical Garden, vol. 75, no. 1, p. 1-34.

LEAL, IR., TABARELLI, M. and SILVA, JMC., 2003. Ecologia e conservação da Caatinga. Recife: Editora da Universidade Federal de Pernambuco, 802p.

LÜTGE, U., 1997. Physiological ecology of tropical plants. Berlin: Springer-Verlag, 384p.

MEDINA, E., 1995. Diversity of life forms of higher plants in neotropical dry forests. In BULLOCK, SH., MOONEY, HA. and MEDINA, E. (eds). Seasonally dry tropical forests. Cambridge: Cambridge University Press, p. 221-242.

MURPHY, PG. and LUGO, AE., 1986. Ecology of tropical dry forests. Annual Review of Ecology and Systematics, vol. 17, no. 1 , p. $67-88$.

PENNINGTON, RT., PRADO, DE. and PENDRY, CA., 2000. Neotropical seasonally dry forests and Quaternary vegetation changes. Journal of Biogeography, vol. 27, no. 2, p. 261-273.

PÔRTO, KC., CABRAL, JJP. and TABARELLI, M., 2004. Brejos de Altitude em Pernambuco e Paraíba: história natural, ecologia e conservação. Brasília: Coleção Biodiversidade no. 9, Ministério do Meio Ambiente, 324p.

TABARELLI, M., VICENTE, A. and BARBOSA, DCA. 2003. Variation of seed dispersal spectrum of woody plants across a rainfall gradient in north-eastern Brazil. Journal of Arid Environments, vol. 53, no. 2, p. 197-210.

VÁZQUEZ, JA. and GIVNISH, TJ., 1998. Altitudinal gradients in tropical forest composition, structure, and diversity in the Sierra de Manantlán. Journal of Ecology, vol. 86, no. 6, p. 999-1020. 